\title{
Effect on Colony Growth Inhibition of Soil-Borne Fungal Pathogens by Available Chlorine Content in Sodium Hypochlorite
}

\author{
Sung-Hee Lee ${ }^{1 *}$, Hyunman Shin ${ }^{1}$, Ju-Hyoung Kim ${ }^{1}$, Kyoung-Yul Ryu ${ }^{2}$, Heung Tae Kim ${ }^{3}$, Byeongjin Cha ${ }^{3}$, \\ and Jae-Soon $\mathrm{Cha}^{3}$ \\ ${ }^{1}$ Bureau of Research \& Development, Chungcheongbuk-do Agricultural Research and Extension Services, Cheongju \\ 28130, Korea \\ ${ }^{2}$ Department of Agro-food Safety and Crop Protection, National Institute of Agricultural Sciences, Rural Development \\ Administration, Wanju 55365, Korea \\ ${ }^{3}$ Department of Plant Medicine, Chungbuk National University, Cheongju 28644, Korea
}

(Received on July 4, 2018; Revised on November 12, 2018; Accepted on December 9, 2018)

Our study investigated the available chlorine content, contact time and difference among strains of each pathogen for sodium hypochlorite $(\mathrm{NaOCl})$ to control chemically against soil-borne fungal pathogens, such as Phytophthora rot by Phytophthora cactorum, violet root rot by Helicobasidium mompa, and white root rot by Rosellinia necatrix, causing die-back symptom on apple trees. As a result, the colony growth of Phytophthora cactorum was inhibited completely by soaking over $5 \mathrm{~s}$ in $31.25 \mathrm{ml} / \mathrm{l}$ available chlorine content of $\mathrm{NaOCl}$. Those of $H$. mompa and $R$. necatrix were inhibited entirely by soaking over $160 \mathrm{~s}$ in 62.5 and $125 \mathrm{ml} / \mathrm{l}$ available chlorine content in $\mathrm{NaOCl}$, respectively. Also, inhibition effect on available chlorine in $\mathrm{NaOCl}$ among strains of each soil-borne pathogen showed no significant difference and was similar to or better than that of fungicides.

Keywords : apple tree die-back, disease control, sodium hypochlorite, soil-borne diseases

Handling Editor : Sang, Mee Kyung

\footnotetext{
*Corresponding author.

Phone) +82-43-220-6561, FAX) +82-43-220-6565

E-mail)darkhorses@korea.kr

(c) This is an Open Access article distributed under the terms of the Creative Commons Attribution Non-Commercial License (http:// creativecommons.org/licenses/by-nc/4.0) which permits unrestricted noncommercial use, distribution, and reproduction in any medium, provided the original work is properly cited.
}

Articles can be freely viewed online at www.ppjonline.org.
Recent changes in climate and cultivation environment have led to the problem of apple tree dieback caused by soil-borne diseases, which causes economic losses (Lee et al., 2016). The major soil-borne diseases reported in Korea are Phytophthora root rot by Phytophthora cactorum, violet root rot by Helicobasidium mompa, and white root rot by Rosellinia necatrix (KSPP, 2009; Lee et al., 2006; RDA, 1993). The apple trees infected with these diseases show remarkably weak leaf growth, poor growth of shoots, early leaf yellowing and abscission, and reduction of fruit yield with low quality. In the case of severe damage, the entire trees become dieback within 2-3 years, and the possibility of re-occurrence is high even after supplementary planting, and eventually it is easy to reach the disused orchards (Kim et al., 1995; Lee et al., 1995; Lee, 2002; Lee et al., 2016).

At present, azoxystrobin for Phytophthora root rot, tolclofos-methyl and thiophanate-methyl for violet root rot, fluazinam and benomyl, isoprothiolane for white root rot are registered as control agents (Korea Crop Protection Association). However, these control agents have been used in most farms suffering from the tree dieback, but they have not had clear control effects, and the annually repetitive supplementary planting is the only alternative to control the diseases resulted in increasing of economic losses.

A variety of chemical disinfestants can be used in disease control. Among them, $\mathrm{NaOCl}$ can be used in seeds (Chun et al., 1997; Sauer and Burroughs, 1986), soil (Bisessar and Mcllveen, 1992), and water systems (Santos-Rufo and Rodriguez-Jurado, 2016) because it meets the registration criteria in terms of human health and environment with wide disinfection effects and a short half-life (WHO, 2011). $\mathrm{NaOCl}$ was first registered in the United States in 1957 as a 
crop protection agent, however, $\mathrm{NaOCl}$ is not yet registered as a control agent in Korea, it is restricted to apply in fields. Nevertheless, because the effect of the registered control agents is insignificant, it is necessary to develop a definite control agent and method for soil-borne diseases which cause dieback in apple trees.

In this study, the inhibition available chlorine content, minimum contact time, and inhibition effect among isolates for $\mathrm{NaOCl}$ on colony growth of the 3 soil-born fungal pathogens, compared with registered control agents was investigated in vitro.

\section{Materials and Methods}

Phytopathogens. Six isolates of Phytophthora cactorum (KACC40166, 40174, 40175, 40176, 40183, and 40448), 2 isolates of Helicobasidium mompa (KACC40169 and 40836), 4 isolates of Rosellinia necatrix (KACC40168, 40445,40446 , and 40447) were distributed from the National Agrobiodiversity Center (https://genebank.rda.go.kr) in Rural Development Administration. Also, 1 isolate of Helicobasidium sp. (CBARES2015V1) and 2 isolates of Rosellinia sp. (CBARES2015W1 and W2) were isolated from apple trees (Lee, 1995; Shikata and Mitsueda, 1978; Singleton et al., 1992; Tadao, 1984). The used medium for culture and experiment was potato dextrose agar (PDA; Difco, Becton, Dickinson and Company, MD, USA).

Tested chemical and fungicides. The chemical used was sodium hypochlorite $(\mathrm{NaOCl}, 8.0 \%$ available chlorine content, Junsei, Japan) for growth inhibition of each pathogen. The fungicides used are as follow; azoxystrobin (WP, a.i. $10 \%$ ) for Phytophthora cactorum, thiophanate-methyl (WP, a.i. 70\%) and tolclofos-methyl (WP, a.i. 50\%) for Helicobasidium mompa and Helicobasidium sp. and fluazinam (WP, a.i. 50\%), benomyl (WP, a.i. 50\%), isoprothiolane (GR, a.i. 12\%) for Rosellinia necatrix and Rosellinia sp.

Experimental design. In order to determine the available chlorine content of $\mathrm{NaOCl}$, cultured agar plug of each phytopathogen colony with Cork borer 2 (Ø $6.2 \mathrm{~mm}$, Usbeck, Radevormwald, Germany) was placed on sterilized paper discs (Ø $8 \times 1.5 \mathrm{~mm}$, Advantec, Japan) on PDA medium and then a cultured agar plug on a paper disc were placed. Six available chlorine content of the chemical were chosen for the in vitro experiments: $1.25,3.125,12.5,31.25,62.5$, $125 \mathrm{ml} / 1$ of $8.0 \% \mathrm{NaOCl}$ in sterilized water. Each available chlorine content was injected into a paper disc by $70 \mu \mathrm{l}$ while being kept cool on ice, and incubated at $23 \pm 1^{\circ} \mathrm{C}$ for 5 to 15 days in MIR-154 (Panasonic, Tokyo, Japan).
To investigate the inhibitory contact time in $\mathrm{NaOCl}$ for each pathogen, 5 agar plugs of each pathogen were soaked in the determined available chlorine content in $\mathrm{NaOCl}$ for $5,10,20,40,80,160,320,640$, and 1,280 s, respectively. They were taken out, put on sterilized absorbent paper, cultured on PDA, and then incubated at $23 \pm 1^{\circ} \mathrm{C}$ for 5 to 15 days.

Inhibition rate for each available chlorine content of Na$\mathrm{OCl}$ was as follows; (control value - value of each available chlorine content of $\mathrm{NaOCl}) /$ control value $\times 100$.

Finally, isolates of the pathogens were tested for showing the inhibition difference within the available chlorine content of $\mathrm{NaOCl}$ determined above as well as the currently registered fungicides.

As the medium preparation, $100 \mathrm{ml}$ of the PDA medium was sterilized and cooled by $50-60^{\circ} \mathrm{C}$, and then the standard or 2-fold amount of each crop protection agent were added. Especially, isoprothiolane was dispensed by $30 \mathrm{ml}$ of PDA medium after adding standard amount $25.5 \mathrm{~g}$ or 2-fold amount $51 \mathrm{~g}$ in $100 \times 40 \mathrm{~mm}$ plant culture dish (SPL Lifesciences Co., Ltd., Gyeonggi, Korea). All treatments were performed 3 times in 3 replications.

Data analysis. The colony growth diameter of each treatment was measured and the inhibition rate compared to non-treatment was calculated. The diameter of the colony growth was measured by the average of long axis and short axis and experiments were tested by 3 times with 5 repetitions per treatment.

Means could be compared to the respective control using the Duncan's test $(P=0.05)$ when DMRT showed significant differences $(P<0.05)$ by using CoStat 6400 program (CoHort software, USA).

\section{Results and Discussion}

Available chlorine content and contact time in $\mathrm{NaOCl}$ for colony growth inhibition of soil-borne fungal pathogens. $P$. cactorum KACC40166 isolate was completely inhibited over $31.25 \mathrm{ml} / 1$ of $\mathrm{NaOCl}$. H. mompa KACC40836 and $R$. necatrix KACC40168 isolate were completely inhibited over 31.25 and $62.5 \mathrm{ml} / 1$ of $\mathrm{NaOCl}$ despite difference among repetitions, respectively (Fig. 1). In addition, as shown in Table 1, P. cactorum KACC40166 isolate showed a significant inhibition rate of $66 \%$ in the colony diameter on available chlorine content of $12.5 \mathrm{ml} / \mathrm{l}$ of NaOCl , compared with the control and no colony formation over $31.25 \mathrm{ml} / 1$ of $\mathrm{NaOCl}$ was showed. H. mompa KACC40836 isolate showed significant inhibition rate of $11 \%, 16 \%$, and $21 \%$ in the colony diameter on $1.25,3.125$, and $12.5 \mathrm{ml} /$ 

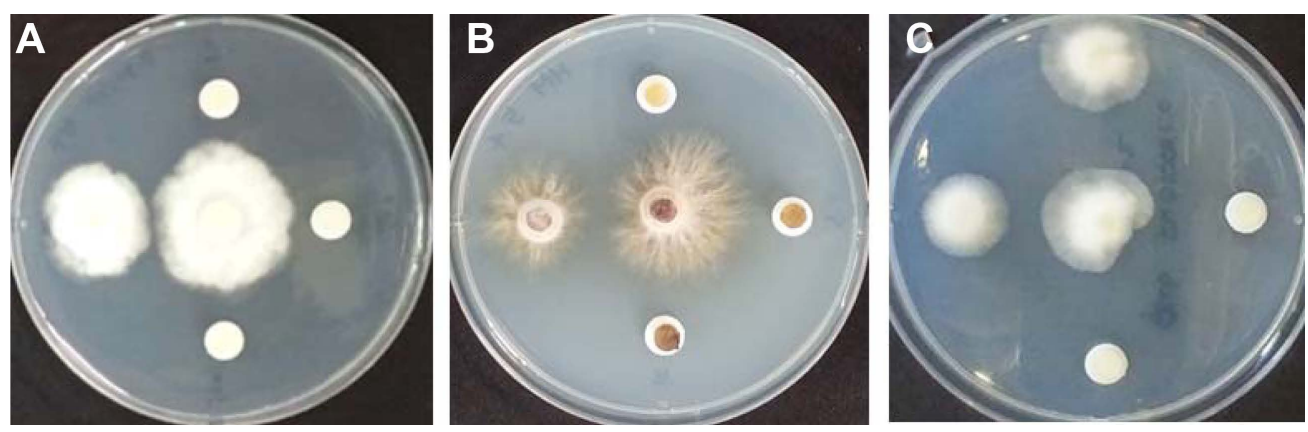

Fig. 1. Representative colony growth inhibition of soil-borne fungal pathogens causing apple tree dieback by available chlorine content in $\mathrm{NaOCl}$ on PDA. Each treated available chlorine content in $\mathrm{NaOCl}$ was 12.5 (left), 31.25, 62.5 and $125 \mathrm{ml} / 1$ on plate (A), (B) and (C), clockwise. The center agar plug on all plates was a control. Test plate A, B and C were for Phytophthora cactorum KACC40166, Helicobasidium mompa KACC40836 and Rosellinia necatrix KACC40168 isolate, respectively.

1 of $\mathrm{NaOCl}$, respectively, compared to the control and no colony formation over $31.25 \mathrm{ml} / \mathrm{l}$ of $\mathrm{NaOCl}$ was showed. There was no significant difference for the colony growth diameter between 1.25 and $3.125 \mathrm{ml} / \mathrm{l}$ as well as 3.125 and $12.5 \mathrm{ml} / 1$ of $\mathrm{NaOCl}$. $R$. necatrix KACC40168 isolate showed significant inhibition rate of $36 \%$ and $61 \%$ in the colony diameter on 31.25 and $62.5 \mathrm{ml} / \mathrm{l}$ of $\mathrm{NaOCl}$, respectively, compared to the control. There was no statistical difference for the colony growth diameter between 31.25 and $62.5 \mathrm{ml} / 1$ of $\mathrm{NaOCl}$ and no colony formation over 125 $\mathrm{ml} / \mathrm{l}$ of $\mathrm{NaOCl}$ was showed. From these results the colony inhibition effect of soil-borne pathogens was different according to available chlorine content of $\mathrm{NaOCl}$, as if the sensitivity of $\mathrm{NaOCl}$ varies according to plant pathogens (Cayanan et al., 2009; Hong et al., 2003; Santos-Rufo and Rodriguez-jurado, 2016; Taylor et al., 2000; Thompson, 1965). Chun et al. (1997) reported that $2.6 \%$ of $\mathrm{NaOCl}$ killed most of bacteria and fungi in rice seeds. Shin et al. (2014) showed that conidia of Gibbrella fujikuroi were significantly inhibited by $0.008-0.01 \%$ of $\mathrm{NaOCl}$ and the control value on $0.3 \%$ and $0.5 \%$ of $\mathrm{NaOCl}$ in the infected rice seeds were $93.1 \%$ and $93.8 \%$, respectively. Sauer and Burroughs (1986) reported inhibition of Aspergillus spp. at $1-5 \%$ concentration $\mathrm{NaOCl}$. Therefore, this available chlorine content of $\mathrm{NaOCl}$ were similar range to the colony inhibition for $P$. cactorum, H. mompa, and R. necatrix.

The results on contact time that inhibits colony formation of each pathogen isolate by the available chlorine content determined above are shown in Table 2. Compared with the control treatment, the $P$. cactorum KACC 40166 isolate showed the significant colony inhibition rate of $6-25 \%$ and $100 \%$ after soaking in $12.5 \mathrm{ml} / 1$ of $\mathrm{NaOCl}$ for $5-20 \mathrm{~s}$ and over $40 \mathrm{~s}$, respectively. In addition, the isolate incubated after soaking in $31.25 \mathrm{ml} / 1$ of $\mathrm{NaOCl}$ over $5 \mathrm{~s}$. showed the significant inhibition rate of $100 \%$ without colony formation. The H. mompa KACC40836 isolate showed no significance after soaking in $31.25 \mathrm{ml} / \mathrm{l}$ of $\mathrm{NaOCl}$ for $5-10$ $\mathrm{s}$. The isolate treated for 20-160 s, whereas, showed the significant inhibition rate of $22-80 \%$ and tended toward the longer the soaking time, the higher the inhibition rate. That

Table 1. Colony inhibition rate for a typical isolate of soil-borne fungal pathogens by available chlorine content of $\mathrm{NaOCl}$ on $\mathrm{PDA}$

\begin{tabular}{|c|c|c|c|c|c|c|}
\hline \multirow{2}{*}{$\begin{array}{c}\text { Available } \\
\text { chlorine } \\
\text { content of } \mathrm{NaOCl} \\
(\mathrm{ml} / \mathrm{l})\end{array}$} & \multicolumn{2}{|c|}{ P. cactorum KACC40166 } & \multicolumn{2}{|c|}{ H. mompa КACC40836 } & \multicolumn{2}{|c|}{ R. necatrix KACC40168 } \\
\hline & $\begin{array}{l}\text { Colony growth } \\
\text { diameter } \\
(\mathrm{mm})\end{array}$ & $\begin{array}{l}\text { Inhibition } \\
\text { rate } \\
(\%)\end{array}$ & $\begin{array}{l}\text { Colony growth } \\
\text { diameter } \\
(\mathrm{mm})\end{array}$ & $\begin{array}{c}\text { Inhibition } \\
\text { rate } \\
(\%)\end{array}$ & $\begin{array}{l}\text { Colony growth } \\
\text { diameter } \\
(\mathrm{mm})\end{array}$ & $\begin{array}{c}\text { Inhibition } \\
\text { rate } \\
(\%)\end{array}$ \\
\hline Control & $28.1 \mathrm{a}$ & - & $31.7 \mathrm{a}$ & - & $31.4 \mathrm{a}$ & - \\
\hline 1.25 & $26.8 \mathrm{a}$ & 5 & $28.3 \mathrm{~b}$ & 11 & $28.7 \mathrm{ab}$ & 9 \\
\hline 3.125 & $25.5 \mathrm{a}$ & 9 & $26.8 \mathrm{bc}$ & 16 & $34.1 \mathrm{a}$ & -9 \\
\hline 12.5 & $9.7 \mathrm{~b}$ & 66 & $25.0 \mathrm{c}$ & 21 & $28.8 \mathrm{ab}$ & 8 \\
\hline 31.25 & $0 \mathrm{c}$ & 100 & $0 \mathrm{~d}$ & 100 & $20.0 \mathrm{bc}$ & 36 \\
\hline 62.5 & $0 \mathrm{c}$ & 100 & $0 \mathrm{~d}$ & 100 & $12.4 \mathrm{c}$ & 61 \\
\hline 125 & $0 \mathrm{c}$ & 100 & $0 \mathrm{~d}$ & 100 & $0 \mathrm{~d}$ & 100 \\
\hline
\end{tabular}

Mean separation by DMRT at $P<0.05$. 
Table 2. Colony inhibition rate for a typical isolate of soil-borne fungal pathogens by soaking time from the determined available chlorine content of $\mathrm{NaOCl}$

\begin{tabular}{|c|c|c|c|c|c|c|c|c|c|c|c|c|}
\hline \multirow{3}{*}{$\begin{array}{c}\text { Soaking } \\
\text { time } \\
\text { (sec.) }\end{array}$} & \multicolumn{4}{|c|}{ P. cactorum KACC40166 } & \multicolumn{4}{|c|}{ H. тотра КАСС 40836} & \multicolumn{4}{|c|}{ R. necatrix KACC40168 } \\
\hline & \multicolumn{2}{|c|}{$\begin{array}{c}12.5 \mathrm{ml} / \mathrm{l} \text { of } \\
\mathrm{NaOCl}\end{array}$} & \multicolumn{2}{|c|}{$\begin{array}{c}31.25 \mathrm{ml} / 1 \text { of } \\
\mathrm{NaOCl}\end{array}$} & \multicolumn{2}{|c|}{$\begin{array}{c}31.25 \mathrm{ml} / 1 \text { of } \\
\mathrm{NaOCl}\end{array}$} & \multicolumn{2}{|c|}{$\begin{array}{c}62.5 \mathrm{ml} / \mathrm{l} \text { of } \\
\mathrm{NaOCl}\end{array}$} & \multicolumn{2}{|c|}{$\begin{array}{c}62.5 \mathrm{ml} / 1 \text { of } \\
\mathrm{NaOCl}\end{array}$} & \multicolumn{2}{|c|}{$\begin{array}{c}125 \mathrm{ml} / \mathrm{l} \text { of } \\
\mathrm{NaOCl}\end{array}$} \\
\hline & $\begin{array}{l}\text { Colony } \\
\text { growth } \\
\text { diameter } \\
(\mathrm{mm})\end{array}$ & $\begin{array}{c}\text { Inhibition } \\
\text { rate } \\
(\%)\end{array}$ & $\begin{array}{l}\text { Colony } \\
\text { growth } \\
\text { diameter } \\
(\mathrm{mm})\end{array}$ & $\begin{array}{c}\text { Inhibition } \\
\text { rate } \\
(\%)\end{array}$ & $\begin{array}{l}\text { Colony } \\
\text { growth } \\
\text { diameter } \\
(\mathrm{mm})\end{array}$ & $\begin{array}{c}\text { Inhibition } \\
\text { rate } \\
(\%)\end{array}$ & $\begin{array}{l}\text { Colony } \\
\text { growth } \\
\text { diameter } \\
(\mathrm{mm})\end{array}$ & $\begin{array}{c}\text { Inhibition } \\
\text { rate } \\
(\%)\end{array}$ & $\begin{array}{l}\text { Colony } \\
\text { growth } \\
\text { diameter } \\
(\mathrm{mm})\end{array}$ & $\begin{array}{c}\text { Inhibition } \\
\text { rate } \\
(\%)\end{array}$ & $\begin{array}{l}\text { Colony } \\
\text { growth } \\
\text { diameter } \\
(\mathrm{mm})\end{array}$ & $\begin{array}{c}\text { Inhibition } \\
\text { rate } \\
(\%)\end{array}$ \\
\hline Control & $25.1 \mathrm{a}$ & - & $28.7 \mathrm{a}$ & - & $24.2 \mathrm{a}$ & - & $26.8 \mathrm{a}$ & - & $27.2 \mathrm{a}$ & - & $33.8 \mathrm{a}$ & - \\
\hline 5 & $23.6 \mathrm{~b}$ & 6 & $0 \mathrm{~b}$ & 100 & $22.1 \mathrm{ab}$ & 9 & $23.2 \mathrm{ab}$ & 13 & $17.8 \mathrm{~b}$ & 35 & $22.4 \mathrm{~b}$ & 34 \\
\hline 10 & $20.5 \mathrm{c}$ & 18 & $0 \mathrm{~b}$ & 100 & $21.7 \mathrm{ab}$ & 10 & $20.6 \mathrm{bc}$ & 23 & $20.3 \mathrm{~b}$ & 25 & $23.0 \mathrm{~b}$ & 32 \\
\hline 20 & $18.8 \mathrm{~d}$ & 25 & - & - & $19.0 \mathrm{~b}$ & 22 & $20.5 \mathrm{bc}$ & 24 & $18.4 \mathrm{~b}$ & 32 & $17.5 \mathrm{c}$ & 48 \\
\hline 40 & $0 \mathrm{e}$ & 100 & - & - & $18.6 \mathrm{bc}$ & 23 & $17.2 \mathrm{c}$ & 36 & $17.9 \mathrm{~b}$ & 34 & $18.0 \mathrm{c}$ & 47 \\
\hline 80 & $0 \mathrm{e}$ & 100 & - & - & $15.3 \mathrm{c}$ & 37 & $4.9 \mathrm{~d}$ & 82 & $16.9 \mathrm{~b}$ & 38 & $17.3 \mathrm{c}$ & 49 \\
\hline 160 & - & - & - & - & $4.8 \mathrm{~d}$ & 80 & $0 \mathrm{e}$ & 100 & $18.4 \mathrm{~b}$ & 32 & $0 \mathrm{~d}$ & 100 \\
\hline 320 & - & - & - & - & $0 \mathrm{e}$ & 100 & $0 \mathrm{e}$ & 100 & $4.2 \mathrm{c}$ & 85 & $0 \mathrm{~d}$ & 100 \\
\hline 640 & - & - & - & - & $0 \mathrm{e}$ & 100 & - & - & $0 \mathrm{~d}$ & 100 & - & - \\
\hline 1,280 & - & - & - & - & - & - & - & - & $0 \mathrm{~d}$ & 100 & - & - \\
\hline
\end{tabular}

Mean separation by DMRT at $P<0.05$.

treated over $320 \mathrm{~s}$. showed the significant inhibition rate of $100 \%$ without colony formation. No significant difference showed among the range of 5-40 $\mathrm{s}$ as well as between 40 and $80 \mathrm{~s}$. Treatments in $62.5 \mathrm{ml} / 1$ of $\mathrm{NaOCl}$ for the $5 \mathrm{~s}$ showed no significant difference. On the other hand, treatments for 10-80 s showed the significant inhibition rate of $23-82 \%$ without difference among the range of either 5-20 $\mathrm{s}$ or $10-40 \mathrm{~s}$. That treated over $320 \mathrm{~s}$ showed the significant inhibition rate of $100 \%$ without colony formation. The $R$. necatrix KACC40168 isolate incubated after soaking in $62.5 \mathrm{ml} / 1$ of $\mathrm{NaOCl}$ for 5-320 s showed significant inhibition rate of 35-85, compared to control, with no significant difference among treatments for 5-160 s. Thus the isolate showed significant inhibition rate of $100 \%$ over $640 \mathrm{~s}$ without colony formation. That treated in $125 \mathrm{ml} / 1$ of $\mathrm{NaOCl}$ for 5-80 s showed significant inhibition rate of 34-49\%, compared to control, with no significant difference between 5 and $10 \mathrm{~s}$. Also, that showed significant inhibition rate of $100 \%$ over $160 \mathrm{~s}$ without colony formation. From these results, the sensitivity of phytopathogens for $\mathrm{NaOCl}$ concentration is consistent with the report that they have different inhibition degree depending on contact time in $\mathrm{NaOCl}$ (Copes et al., 2001; Datnoff et al., 1987; Johnson et al., 1997; Santos-Rufo and Rodriguez-jurado, 2016; Segall, 1968).

Shin et al. (2014) reported that the conidia of Fusarium fujikuroi showed significant inhibition of the colony formation after treatment in $0.006 \%$ of $\mathrm{NaOCl}$ for $120 \mathrm{~min}$.
Cayanan et al. (2009) reported that the zoospores of P. cactorum showed complete inhibition after treatment in free chlorine of $0.3 \mathrm{ml} / 1$ for $6 \mathrm{~min}$. Meanwhile, Jeffers (1992) reported that the apple root stock MM.106 treated in 1.05\% of $\mathrm{NaOCl}$ for 10 min. were fewer plants diseased by Phytophthora root rot as well as increased significantly both shoot length and fresh weight of root than the control that soaked in water. Thus, the root stock treated for $60 \mathrm{~min}$. showed no significance with phytotoxic, compared to the control soaked in water.

Effect on colony growth inhibition of soil-borne pathogens by available chlorine content in $\mathrm{NaOCl}$. On the basis of above determined available chlorine content in $\mathrm{NaOCl}$, Table 3 to 5 showed the inhibition effect of colony growth for the isolates of each pathogen with control fungicides. From the results of Table 3, P. cactorum KACC40175, 40176, 40183, and 40448 isolate showed the significant inhibition rate of $45,80,76$, and $18 \%$ on 12.5 $\mathrm{ml} / \mathrm{l}$ of $\mathrm{NaOCl}$, respectively. On $31.25 \mathrm{ml} / \mathrm{l}$ of $\mathrm{NaOCl}$ the 6 isolates showed significant inhibition rate of $100 \%$ without colony growth. On the standard dose of a control fungicide, azoxystrobin WP, $P$. cactorum KACC40175, 40183, and 40448 isolate showed significant inhibition rate of 29,45 , and $42 \%$, respectively. On the double dose, P. cactorum KACC40174, 40175, 40183, and 40448 isolate showed significant inhibition rate of 29,53 , and $45 \%$, respectively. Also, $P$. cactorum KACC40166, 40174, 40175, and 40183 
Table 3. Colony inhibition rate of 6 isolates for Phytophthora cactorum by available chlorine content of $\mathrm{NaOCl}$ and a fungicide

\begin{tabular}{|c|c|c|c|c|c|c|c|c|c|c|c|c|}
\hline \multirow[b]{2}{*}{ Treatments } & \multicolumn{2}{|c|}{ KACC40166 } & \multicolumn{2}{|c|}{ KACC40174 } & \multicolumn{2}{|c|}{ KACC40175 } & \multicolumn{2}{|c|}{ KACC40176 } & \multicolumn{2}{|c|}{ KACC40183 } & \multicolumn{2}{|c|}{ KACC40448 } \\
\hline & $\begin{array}{l}\text { Colony } \\
\text { growth } \\
\text { diameter } \\
(\mathrm{mm})\end{array}$ & $\begin{array}{l}\text { Inhibi- } \\
\text { tion } \\
\text { rate } \\
(\%) \\
\end{array}$ & $\begin{array}{l}\text { Colony } \\
\text { growth } \\
\text { diameter } \\
(\mathrm{mm})\end{array}$ & $\begin{array}{l}\text { Inhibi- } \\
\text { tion } \\
\text { rate } \\
(\%) \\
\end{array}$ & $\begin{array}{l}\text { Colony } \\
\text { growth } \\
\text { diameter } \\
(\mathrm{mm})\end{array}$ & $\begin{array}{l}\text { Inhibi- } \\
\text { tion } \\
\text { rate } \\
(\%) \\
\end{array}$ & $\begin{array}{l}\text { Colony } \\
\text { growth } \\
\text { diameter } \\
(\mathrm{mm})\end{array}$ & $\begin{array}{l}\text { Inhibi- } \\
\text { tion } \\
\text { rate } \\
(\%) \\
\end{array}$ & $\begin{array}{l}\text { Colony } \\
\text { growth } \\
\text { diameter } \\
(\mathrm{mm})\end{array}$ & $\begin{array}{l}\text { Inhibi- } \\
\text { tion } \\
\text { rate } \\
(\%)\end{array}$ & $\begin{array}{l}\text { Colony } \\
\text { growth } \\
\text { diameter } \\
(\mathrm{mm})\end{array}$ & $\begin{array}{l}\text { Inhibi- } \\
\text { tion } \\
\text { rate } \\
(\%)\end{array}$ \\
\hline Control & $30.9 \mathrm{a}$ & - & $28.2 \mathrm{a}$ & - & $28.9 \mathrm{a}$ & - & $30.0 \mathrm{a}$ & - & $26.9 \mathrm{a}$ & - & $25.1 \mathrm{a}$ & - \\
\hline $\begin{array}{l}12.5 \mathrm{ml} / 1 \\
\text { of } \mathrm{NaOCl}\end{array}$ & $20.2 \mathrm{a}$ & 35 & $19.3 \mathrm{ab}$ & 32 & $15.9 \mathrm{~b}$ & 45 & $5.9 \mathrm{~b}$ & 80 & $6.5 \mathrm{bc}$ & 76 & $20.7 \mathrm{~b}$ & 18 \\
\hline $\begin{array}{c}31.25 \mathrm{ml} / 1 \\
\text { of } \mathrm{NaOCl}\end{array}$ & $0 \mathrm{~b}$ & 100 & $0 \mathrm{c}$ & 100 & $0 \mathrm{c}$ & 100 & $0 \mathrm{~b}$ & 100 & $0 \mathrm{c}$ & 100 & $0 \mathrm{~d}$ & 100 \\
\hline $1 \times$ azoxystrobin & $20.7 \mathrm{a}$ & 33 & $14.7 \mathrm{ab}$ & 48 & $16.2 \mathrm{~b}$ & 44 & $21.4 \mathrm{a}$ & 29 & $14.7 \mathrm{~b}$ & 45 & $14.5 \mathrm{c}$ & 42 \\
\hline $2 \times$ azoxystrobin & $20.2 \mathrm{a}$ & 35 & $12.4 \mathrm{bc}$ & 56 & $15.4 \mathrm{~b}$ & 47 & $21.4 \mathrm{a}$ & 29 & $12.6 \mathrm{~b}$ & 53 & $13.8 \mathrm{c}$ & 45 \\
\hline
\end{tabular}

Mean separation by DMRT at $P<0.05$.

Table 4. Colony inhibition rate of 3 isolates for Helicobasidium mompa and Helicobasidium sp. by available chlorine content of $\mathrm{NaOCl}$ and 2 fungicides

\begin{tabular}{|c|c|c|c|c|c|c|}
\hline \multirow[b]{2}{*}{ Treatments } & \multicolumn{2}{|c|}{ KACC40169 } & \multicolumn{2}{|c|}{ KACC40836 } & \multicolumn{2}{|c|}{ CBARES20151 } \\
\hline & $\begin{array}{l}\text { Colony growth } \\
\text { diameter } \\
(\mathrm{mm})\end{array}$ & $\begin{array}{l}\text { Inhibition } \\
\text { rate } \\
(\%)\end{array}$ & $\begin{array}{l}\text { Colony growth } \\
\text { diameter } \\
(\mathrm{mm})\end{array}$ & $\begin{array}{l}\text { Inhibition } \\
\text { rate } \\
(\%)\end{array}$ & $\begin{array}{l}\text { Colony growth } \\
\text { diameter } \\
(\mathrm{mm})\end{array}$ & $\begin{array}{c}\text { Inhibition } \\
\text { rate } \\
(\%)\end{array}$ \\
\hline Control & $15.3 \mathrm{a}$ & - & $12.3 \mathrm{a}$ & - & $9.5 \mathrm{a}$ & - \\
\hline $31.25 \mathrm{ml} / \mathrm{l}$ of $\mathrm{NaOCl}$ & $3.9 \mathrm{c}$ & 75 & $2.9 \mathrm{c}$ & 76 & $1.2 \mathrm{c}$ & 87 \\
\hline $62.5 \mathrm{ml} / 1$ of $\mathrm{NaOCl}$ & $0 \mathrm{~d}$ & 100 & $0 \mathrm{~d}$ & 100 & $0 \mathrm{c}$ & 100 \\
\hline $1 \times$ thiophanate-methyl & $8.8 \mathrm{~b}$ & 43 & $6.9 \mathrm{~b}$ & 44 & $6.4 \mathrm{~b}$ & 33 \\
\hline $2 \times$ thiophanate-methyl & $8.2 \mathrm{~b}$ & 46 & $6.6 \mathrm{~b}$ & 46 & $6.7 \mathrm{~b}$ & 30 \\
\hline $1 \times$ tolclofos-methyl & $9.9 \mathrm{~b}$ & 35 & $8.8 \mathrm{~b}$ & 29 & $9.1 \mathrm{a}$ & 4 \\
\hline $2 \times$ tolclofos-methyl & $9.3 \mathrm{~b}$ & 39 & $7.6 \mathrm{~b}$ & 38 & $8.4 \mathrm{a}$ & 12 \\
\hline
\end{tabular}

Mean separation by DMRT at $P<0.05$.

isolate showed no significant difference between $12.5 \mathrm{ml} /$ 1 of $\mathrm{NaOCl}$ and the fungicide without distinction of treatment dose. P. cactorum KACC40176 isolate was inhibited significantly by rather $12.5 \mathrm{ml} / \mathrm{l}$ of $\mathrm{NaOCl}$ than the fungicide and $P$. cactorum KACC40448 isolate showed the opposite. P. cactorum KACC40174 isolate showed no significant difference between $31.25 \mathrm{ml} / 1$ of $\mathrm{NaOCl}$ and 2-fold dose treatment of the fungicide and both $P$. cactorum KACC40176 and 40183 isolate showed no significance between 12.5 and $31.25 \mathrm{ml} / \mathrm{l}$ of $\mathrm{NaOCl}$ treatment (Table 3). As only azoxystrobin WP was registered as a control agent and possible the occurrence of the fungicide-resistant isolate with annual use (2015 APS Annual Meeting, http:// www.apsnet.org/meetings/Documents/2015_meeting abstracts/aps2015abP667.htm), therefore, we suggest that 12.5-31.25 ml/1 of NaOCl treatment would be effective to control the Phytophthora root rot without the concern for resistant isolate.

From the results of colony inhibition rate for Helicoba- sidium sp. CBARES20151, H. mompa KACC40169, and KACC40836 isolate, the 3 isolates showed significant inhibition rate of $75-87 \%$ and all $100 \%$ in 31.25 and $62.5 \mathrm{ml} /$ 1 of $\mathrm{NaOCl}$ treatment, respectively, compared to control. Thus, those treated by each available chlorine content of $\mathrm{NaOCl}$ showed significant difference compared to standard and double dose of 2 control fungicides, thiophanatemethyl and tolclofos-methyl. Compared to control, the 3 isolates showed significant inhibition rate of $30-46 \%$, regardless of thiophanate-methyl treatment dose. Also, $H$. mompa KACC40169 and KACC40836 isolate showed significant inhibition rate of 29-39\%, but Helicobasidium sp. CBARES20151 isolate showed no significant difference, regardless of tolclofos-methyl treatment dose (Table 4). As reports of FRAC Code list 1 (2017), these results indicate that the resistant isolates for thiophanate-methyl and tolclofos-methyl were possible to occur, according to use the fungicides over 20 years. In fact, Fernández-Ortuño and Schnabel (2012) reported Botrytis cinerea that showed 
Table 5. Colony inhibition rate of 6 isolates for Rosellinia necatrix and Rosellinia sp. by available chlorine content of NaOCl and 3 fungicides

\begin{tabular}{|c|c|c|c|c|c|c|c|c|c|c|c|c|}
\hline \multirow[b]{2}{*}{ Treatments } & \multicolumn{2}{|c|}{ KACC40168 } & \multicolumn{2}{|c|}{ KACC40445 } & \multicolumn{2}{|c|}{ KACC40446 } & \multicolumn{2}{|c|}{ KACC40447 } & \multicolumn{2}{|c|}{ CBARES20152 } & \multicolumn{2}{|c|}{ CBARES20153 } \\
\hline & $\begin{array}{l}\text { Colony } \\
\text { growth } \\
\text { diameter } \\
(\mathrm{mm})\end{array}$ & $\begin{array}{l}\text { Inhibi- } \\
\text { tion rate } \\
(\%)\end{array}$ & $\begin{array}{l}\text { Colony } \\
\text { growth } \\
\text { diameter } \\
(\mathrm{mm})\end{array}$ & $\begin{array}{c}\text { Inhibi- } \\
\text { tion rate } \\
(\%)\end{array}$ & $\begin{array}{l}\text { Colony } \\
\text { growth } \\
\text { diameter } \\
(\mathrm{mm})\end{array}$ & $\begin{array}{c}\text { Inhibi- } \\
\text { tion rate } \\
(\%)\end{array}$ & $\begin{array}{l}\text { Colony } \\
\text { growth } \\
\text { diameter } \\
(\mathrm{mm})\end{array}$ & $\begin{array}{c}\text { Inhibi- } \\
\text { tion rate } \\
(\%)\end{array}$ & $\begin{array}{l}\text { Colony } \\
\text { growth } \\
\text { diameter } \\
(\mathrm{mm})\end{array}$ & $\begin{array}{c}\text { Inhibi- } \\
\text { tion rate } \\
(\%)\end{array}$ & $\begin{array}{l}\text { Colony } \\
\text { growth } \\
\text { diameter } \\
(\mathrm{mm})\end{array}$ & $\begin{array}{l}\text { Inhibi- } \\
\text { tion rate } \\
(\%)\end{array}$ \\
\hline Control & $23.8 \mathrm{a}$ & - & $17.3 \mathrm{a}$ & - & $29.5 \mathrm{a}$ & - & $26.0 \mathrm{a}$ & - & $24.4 \mathrm{a}$ & - & $13.1 \mathrm{a}$ & - \\
\hline $\begin{array}{l}62.5 \mathrm{ml} / 1 \\
\text { of } \mathrm{NaOCl}\end{array}$ & $8.1 \mathrm{~b}$ & 66 & $11.0 \mathrm{ab}$ & 36 & $20.3 \mathrm{~b}$ & 31 & $20.7 \mathrm{~b}$ & 20 & $7.0 \mathrm{~b}$ & 71 & $2.2 \mathrm{bc}$ & 83 \\
\hline $\begin{array}{l}125 \mathrm{ml} / 1 \\
\text { of } \mathrm{NaOCl}\end{array}$ & $0 \mathrm{c}$ & 100 & $0 \mathrm{c}$ & 100 & $0 \mathrm{e}$ & 100 & $0 \mathrm{~d}$ & 100 & $0 \mathrm{~b}$ & 100 & $0 \mathrm{c}$ & 100 \\
\hline $1 \times$ benomyl & $0 \mathrm{c}$ & 100 & $0 \mathrm{c}$ & 100 & $0 \mathrm{e}$ & 100 & $0 \mathrm{~d}$ & 100 & $0 \mathrm{~b}$ & 100 & $0 \mathrm{c}$ & 100 \\
\hline $2 \times$ benomyl & $0 \mathrm{c}$ & 100 & $0 \mathrm{c}$ & 100 & $0 \mathrm{e}$ & 100 & $0 \mathrm{~d}$ & 100 & $0 \mathrm{~b}$ & 100 & $0 \mathrm{c}$ & 100 \\
\hline $1 \times$ fluazinam & $5.2 \mathrm{bc}$ & 78 & $6.0 \mathrm{bc}$ & 65 & $6.3 \mathrm{~cd}$ & 79 & $5.5 \mathrm{c}$ & 79 & $5.7 \mathrm{~b}$ & 77 & $5.5 \mathrm{~b}$ & 58 \\
\hline $2 \times$ fluazinam & $5.4 \mathrm{bc}$ & 77 & $5.8 \mathrm{bc}$ & 67 & $6.8 \mathrm{c}$ & 77 & $5.4 \mathrm{c}$ & 79 & $5.6 \mathrm{~b}$ & 77 & $5.9 \mathrm{~b}$ & 55 \\
\hline $\begin{array}{c}1 \times \text { isopro- } \\
\text { thiolane }\end{array}$ & $3.8 \mathrm{bc}$ & 84 & $3.9 \mathrm{bc}$ & 78 & $3.7 \mathrm{~d}$ & 88 & $3.5 \mathrm{~cd}$ & 87 & $3.8 \mathrm{~b}$ & 84 & $3.3 \mathrm{bc}$ & 75 \\
\hline $\begin{array}{c}2 \times \text { isopro- } \\
\text { thiolane }\end{array}$ & $3.8 \mathrm{bc}$ & 84 & $4.0 \mathrm{bc}$ & 77 & $3.6 \mathrm{~d}$ & 88 & $1.7 \mathrm{~cd}$ & 94 & $2.1 \mathrm{~b}$ & 91 & $3.4 \mathrm{bc}$ & 74 \\
\hline
\end{tabular}

Mean separation by DMRT at $P<0.05$.

the resistance for thiophanate-methy as well as Van Bruggen and Arneson (1984) reported Rhizoctonia solani that showed the resistance for tolclofos-methyl. Therefore, we suggest that 31.25-62.5 ml/1 of NaOCl treatment would be effective to control the violet root rot diseased by H. mompa.

From the results of colony inhibition rate for Rosellinia sp. CBARES20152 and CBARES20153, R. necatrix KACC40168, KACC40445, KACC40446, and KACC40447 isolate, the other isolates except for $R$. necatrix KACC40445 showed significant inhibition rate of 20$83 \%$ in $62.5 \mathrm{ml} / 1$ of $\mathrm{NaOCl}$ treatment. All of the 6 isolates showed significant inhibition rate of $100 \%$ in $125 \mathrm{ml} / 1$ of $\mathrm{NaOCl}$ treatment. For standard dose and 2-fold dose of the fungicides, such as benomyl, fluazinam and isoprothiolane, all of the 6 isolates showed significant inhibition rate of $100 \%$ in benomyl treatments. However, the other isolates except for $R$. necatrix KACC40446 showed significant inhibition rate of $55-79 \%$ and $74-94 \%$ in fluazinam and isoprothiolane treatment, respectively. Difference between standard and 2-fold treatments in the each fungicide showed no significance (Table 5). From this result, the fungicide, benomyl, was the most effective fungicide to inhibit the colony of white root rot. Yukita (2003) reported that soaking treatment for $20 \mathrm{~min}$ in 500 -fold diluted solution of a fungicide, Fluazinam (a.i. 39.5\%), showed high control value at both laboratory and field experiments against $H$. mompa and R. necatrix. Nevertheless, Eguchi et al. (2008) reported that white root rot of pear trees re-occurred 2 years after fluazinam treatment in Japan. Meanwhile, Takaya et al. (1976) reported that soaking treatment for $24 \mathrm{~h}$ in 1,000fold diluted solution of a fungicide, benomyl (a.i. 50\%), showed significant control effect against white root rot as well as Komori and Nakamura (1985) reported that 1,000 ppm of benomyl or isoprothiolane inhibited completely the isolate of $R$. necatrix.

Recently, FRAC Code list 1 (2017) reported that all of the tested fungicides were concerned by occurrence of resistant isolates. In fact, there were reported that a resistance isolate for benomyl in Rosellinia necatrix occurred (LópezHerrera and Zea-Bonilla, 2007), a cross-resistance isolate for isoprothiolane in Magnaporthe oryzae occurred (Ishii and Hollomon, 2015), a resistance mutant isolate for fluazinam in Botrytis cinerea induced (Shao et al., 2015).

In conclusion, our study showed that pathogens caused soil-borne diseases, Phytophthora root rot, violet root rot, and white root rot, were effectively inhibited by 12.5-31.25 $\mathrm{ml} / 1,31.25-62.5 \mathrm{ml} / 1$, and $62.5-125 \mathrm{ml} / 1$ of $\mathrm{NaOCl}$, respectively.

\section{Acknowledgments}

This work was carried out with the support of Chungcheongbuk-do Agricultural Research and Extension Ser- 
vices (Project No. LP0035762017), funded by Governor of Chungcheongbuk-do as well as 'Cooperative Research Program for Agriculture Science and Technology Development (Project No. PJ0100142016)' Rural Development Administration, Republic of Korea.

\section{References}

Bisessar, S. and Mcllveen, W. D. 1992. Effects of swimming pool sanitizing chemicals on turf grass. Bull. Environ. Contam. Toxicol. 49:295-299.

Cayanan, D. F., Zhang, P., Liu, W., Dixon, M. and Zheng, Y. 2009. Efficacy of chlorine in controlling five common plant pathogens. HortScience 44:157-163.

Chun, S. C., Schneider, R. W. and Cohn, M. A. 1997. Sodium hypochlorite: Effect of solution $\mathrm{pH}$ on rice seed disinfestation and its direct effect on seedling growth. Plant Dis. 81:821824.

Copes, W. E., Chastagner, G. A. and Hummel, R. L. 2001. Influence of select inorganic elements and $\mathrm{pH}$ on the fungicidal activity of chlorine dioxide in water. SNA Res. Conf. Proc. 46:284-286.

Datnoff, L. E., Kroll, T. K. and Lacy, G. H. 1987. Efficacy of chlorine for decontaminating water infested with resting spores of Plasmodiophora brassicae. Plant Dis. 71:734-736.

Eguchi, N., Kawai, Y. and Yamagishi, N. 2008. Long-term evaluation of fluazinam soil drench against white root rot on Japanese pear. Annu. Rep. Kanto Tosan Plant Prot. Soc. 55:159163.

Fernández-Ortuño, D. and Schnabel, G. 2012. First report of thiophanate-methyl resistance in Botrytis cinerea on strawberry from South Carolina. Plant Dis. 96:1700.2

FRAC. 2017. FRAC Code List 2017: Fungicides sorted by mode of action (including FRAC Code numbering). URL https://cpb-us-w2.wpmucdn.com/u.osu.edu/dist/b/28945/ files/2017/04/frac-code-list-2017-final-1juq211.pdf [26 February 2019].

Hong, C. X., Richardson, P. A., Kong, P. and Bush, E. A. 2003. Efficacy of chlorine on multiple species of Phytophthora in recycled nursery irrigation water. Plant Dis. 87:1183-1189.

Ishii, H. and Hollomon, D. W. 2015. Fungicide resistance in plant pathogens. Springer Japan, Ibaraki, Japan. 490 pp.

Jeffers, S. N. 1992. Preplant root treatments to reduce the incidence of Phytophthora species on dormant apple rootstocks. Plant Dis. 76:12-19.

Johnson, C. H., Rice, E. W. and Reasoner, D. J. 1997. Inactivation of Helicobacter pylori by chlorination. Appl. Environ. Microbiol. 63:4969-4970.

Kim, S.-I., Lee, S.-B. and Choi, Y.-M. 1995. Isolation and identification of antagonistic microorganisms for biological control of apple root rot disease. RDA J. Agric. Sci. 37:29-42 (in Korean).

Komori, S. and Nakamura, M. 1985. Effects of several kind of fungicides on apple white root rot. Proc. Kanto-Tosan Plant Prot. Soc. 32:135-136.

KSPP. 2009. List of plant diseases in Korea. 5th ed. The Korean Society of Plant Pathology, Suwon, Korea (in Korean).

Lee, D. H. 2002. Etiology and ecology of apple white root rot, caused by Rosellinia necatrix and its biological control. Ph.D. thesis. Kyungpook National University, Daegu, Korea.

Lee, D. H., Lee, S. W., Choi, K. H., Kim, D. A and Uhm, J. Y. 2006. Survey on the occurrence of apple diseases in Korea from 1992 to 2000. Plant Pathol. J. 22:375-380.

Lee, S. B. 1995. Etiology and epidemiology of white- and violetroot rot caused by Rosellinia necatrix and Helicobasidium mompa on apple tree and their control in Korea. Ph.D. thesis. Chungbuk National University, Cheongju, Korea (in Korean).

Lee, S. B., Chung, B. K., Jang, H. I., Kim, K. H. and Choi, Y. M. 1995. Incidence of soil-borne diseases in apple orchards in Korea. Korean J. Plant Pathol. 11:132-138 (in Korean).

Lee, S.-H., Kwon, Y., Shin, H., Kim, I.-J., Nam, S.-Y., Hong, E. Y., Kwon, S.-I., Kim, D. and Cha, J.-S. 2016. Dieback of apple tree by major soil borne diseases in Chungbuk province from 2013 to 2015. Res. Plant Dis. 22:198-201 (in Korean).

López-Herrera, C. J. and Zea-Bonilla, T. 2007. Effects of benomyl, carbendazim, fluazinam and thiophanate methyl on white root rot of avocado. Crop Prot. 26:1186-1192.

RDA. 1993. Compendium of fruit tree diseases with color plates. Rural Development Administration, Suwon, Korea. 286 pp.

Santos-Rufo, A. and Rodriguez-Jurado, D. 2016. Evaluation of chemical disinfestants in reducing Verticillium dahlia conidia in irrigation water. Crop Prot. 79:105-116.

Sauer, D. B. and Burroughs, R. 1986. Disinfection of seed surfaces with sodium hypochlorite. Phytopathology 76:745-749.

Segall, R. H. 1968. Fungicidal effectiveness of chlorine as influenced by concentration, temperature, $\mathrm{pH}$, and spore exposure time. Phytopathology 58:1412-1414.

Shao, W., Zhang, Y., Ren, W. and Chen, C. 2015. Physiological and biochemical characteristics of laboratory induced mutants of Botrytis cinerea with resistance to fluazinam. Pestic. Biochem. Physiol. 117:19-23.

Shikata, H. and Mitsueda, T. 1978. A method for isolating the white root rot pathogen, Rosellinia necatrix Berl. in soil. $J$. Seric. Sci. Japan 47:519-526.

Shin, D. B., Goh, J., Lee, B.-C., Kang, I. J. and Kang, H.-W. 2014. Use of sodium hypochlorite for the control of bakanae disease in rice. Res. Plant Dis. 20:259-263 (in Korean).

Singleton, L. L., Mihail, J. D. and Rush, C. M. 1992. Methods for research on soilborne phytopathogenic fungi. 2nd ed. APS Press, St. Paul, MN, USA. 265 pp.

Tadao, U. I. 1984. Handbook of soil-borne diseases. Japan Plant Protection Association. Tokyo, Japan. 349 pp.

Takaya, S., Fukuda, T., Kasai, K., Ôike, Y., Yoshida, T., Chikaoka, I. and Kato, S. 1976. Effects of thiophanate-methyl and benomyl against white root rot of tea. Tea Res. J. 44:22-26 (in Japanese).

Taylor, R. H., Falkinham, J. O. 3rd, Norton, C. D. and LeCheval- 
lier, M. W. 2000. Chlorine, chloramine, chlorine dioxide, and ozone susceptibility of Mycobacterium avium. Appl. Environ. Microbiol. 66:1702-1705.

Thompson, D. L. 1965. Control of bacterial stalk rot of corn by chlorination of water in sprinkler irrigation. Crop Sci. 5:369370.

Van Bruggen, A. H. C. and Arneson, P. A. 1984. Resistance in Rhizoctonia solani to tolclofos methyl. Neth. J. Plant Pathol.
90:95-106

WHO. 2011. Guidelines for drinking-water quality. 4th ed. World Health Organization, WHO Press, Geneva, Switzerland. 110 pp.

Yukita, K. 2003. Preventive effects of fluazinam on white and violet root rots of apple trees by dipping method. Annu. Rep. Plant Prot. North Japan 2003:81-84. 